\title{
Research ARticle: Standardization of organic protocols for growth and seed yield of multiplier onion (Allium cepa var. aggregatum) cv. Co (On 5)
}

K. Sundharaiya, S. Nagarai and G. Sathish

Article Chronicle :

Received :

10.07.2020;

Revised:

03.10.2020;

Accepted :

22.10 .2020

KeY WoRds:

Multiplier onion, Allium cepa

var.aggregatum, Organic manure, Bio stimulant onion.
SUMMARY : Afield experiment on Effect of organic manures and biostimulants on growth and seed yield of multiplier onion (Allium cepa var. aggregatum) cv. Co (On 5) was conducted at Agricultural Research Station, Vaigaidam. The experiment was laid out in a Factorial Randomized Block Design with two factors viz., organic manures and biostimulants which includes $\mathrm{M}_{1}$ Control, $\mathrm{M}_{2}-\mathrm{FYM}\left(12.5 \mathrm{t} \mathrm{ha}^{-1}\right)$, $\mathrm{M}_{3}$ - Neem cake ( $\left.2 \mathrm{t} \mathrm{ha}^{-1}\right)$ and $\mathrm{M}_{4}$ - Vermicompost $\left(2 \mathrm{tha}^{-1}\right)$ and $\mathrm{S}_{1}$ - Control (water spray), $\mathrm{S}_{2-}$ Humic acid $(0.2 \%), \mathrm{S}_{3-}$ Panchagavya $(2 \%), \mathrm{S}_{4-}$ Vermiwash $(2 \%)$ and $\mathrm{S}_{5-}$ Seaweed extract (2\%). Totally twenty treatments and were replicated thrice. The results revealed that soil application of FYM@12.5 $\mathrm{tha}^{-1}$ recorded higher plant growth bulb yield and seed yield when compared to other organic manures of the present study. Similarly among the bio stimulants 2 per cent seaweed extract spray recorded higher plant growth, bulb yield and seed yield when compared to other bio stimulants of the present study. Interaction effect also showed that soil application of FYM @ $12.5 \mathrm{t} \mathrm{ha}^{-1}$ and foliar application of seaweed extract excelled and recoded the maximum plant growth, bulb yield and seed yield in multiplier

How to cite this article : Sundharaiya, K., Nagarai, S. and Sathish, G. (2020). Standardization of organic protocols for growth and seed yield of multiplier onion (Allium cepa var. aggregatum) cv. Co (On 5). Agric. Update, 15(4): 374-381; DOI : 10.15740/HAS/AU/15.4/374-381. Copyright@ 2020: Hind Agri-Horticultural Society.
Author for correspondence :

\section{G. Sathish}

Regional Research

Station (T.N.A.U.),

Vridhachalam, Cuddalore

(T.N.) India

Email: gskspice@gmail. com

See end of the article for authors' affiliations 